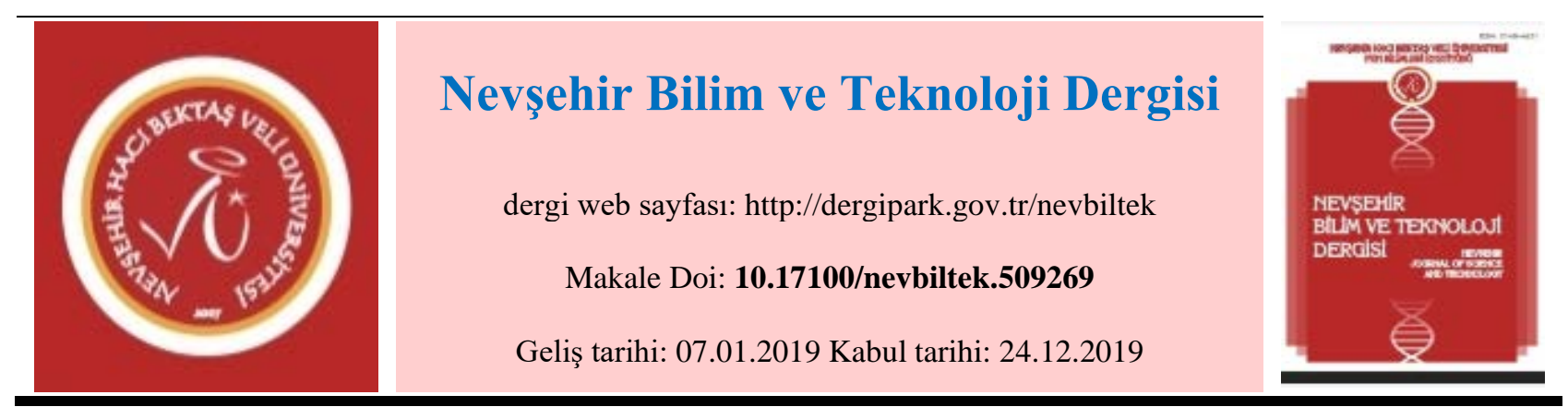

\title{
Sağlık Alanında Kullanılan Biyomateryallerde Biyouyumluluk 1
}

\author{
Zülfü TÜYLEK ${ }^{1,}$ \\ ${ }^{1}$ Malatya Turgut Özal Üniversitesi, Yeşilyurt Meslek Yüksekokulu, Elektronik ve Otomasyon Bölümü, Malatya \\ ORCID ID: 0000000290861327
}

$\ddot{0 z}$

Günümüzde, materyal bilimi alanındaki hızlı gelişmeler, özellikle insan yaşamının hayati önem taşıyan unsurlarından kaynaklanan yapısal çözümleri giderek artırmaktadır. Bu yapısal çözümlerde, en yaygın materyal grubu biyolojik kökene dayalı materyallerdir. Hangi sektör olursa olsun biyo kaynaklı materyallere yer verildiğinde daha doğal tasarımların gerçekleştirilmesine neden olacaktır. Bunun temeli, insan yapısıyla birlikte kullanılan materyalin uyumlu olmasıdır. Bugün bu özellik biyouyumluluk olarak adlandırılmaktadır. Biyouyumluluk, biyolojik ortamın bir materyali kabul etme kabiliyetidir. Özellikle bu materyaller, doğal veya yapay olarak elde edilebilecek materyallerdir. Her materyalde olduğu gibi bu tip materyallerde biyouyumluluk, toksik ve kanserojen olmaması, kimyasal inert ve kararlı olmaması, uygun mekanik dayanıklılık, uygun yorulma ömrü, uygun ağırlık ve yoğunluk, ucuzluk, tekrar kullanılabilirlik, büyük ölçekli imalat ve işleme uygun olması aranılan özellikler içinde yer almaktadır. Biyomateryallerin insan yaşamındaki mükemmel konumu nedeniyle, fizikokimyasal özelliklerinin bulunmasında yeni yaklaşımlar getirilmesi ve biyouyumluluğun iyileştirilmesi için yeni yöntemler geliştirilmesi, yeni biyomateryallerin tıpta kullanımı için çok önemlidir.

Bu çalışmada, insan vücudunun çeşitli kısımlarında çeşitli amaçlar için kullanılan materyallerin biyouyumluluğu üzerinde durulacaktır. Bu nedenle biyomateryaller ve biyomateryallerin bulunduğu biyolojik ortam incelenmelidir. Geleceğin materyalleri arasında yer alan biyomateryallerin üretiminde ve kullanımındaki gelişmeler, yeni tasarımların hayata geçirilmesine büyük katkı sağlayacaktır. Geleceğin malzemeleri arasında yer alan biyomalzemelerin gereksinimlerini bilmek, tasarlanacak ürünlerin elde edilmesine katkıda bulunacaktır.

Anahtar Kelimeler: Biyolojik ortam; biyolojik test; biyomateryaller; biyouyumluluk.

\section{Biocompatibility in Biomaterials Used in Health Field}

\begin{abstract}
Today, rapid developments in the field of material science are increasingly increasing structural solutions resulting from vital elements of human life. In these structural solutions, the most common material group is materials based on biological origin. No matter which sector, it will cause more natural designs to be realized when biomaterials are included. Based on this, is compatibility of the material used together with the human structure. Today, this feature is called biocompatibility. Biocompatibility is the ability of the biological environment to accept an material. In particular these materials, are materials that can be obtained either naturally or artificially. As with any material such materials, are well-suited for use in biocompatibility, toxicity and not carcinogenic, chemical inert and not stable, appropriate mechanical strength, appropriate fatigue life, appropriate weight and density, cheapness, reusability, large scale fabrication and processing. Due to the great location of biomaterials in human life, to introduce new approach in finding out their of physicochemical properties and to develop new methods improving biocompatibility are very important for the utilization of the new biomaterials in medicine.
\end{abstract}

Sorumlu yazar e-mail: zulfu.tuylek@ozal.edu.tr 
This work will focus on the biocompatibility of materials used for various purposes in various parts of the human body. Therefore, the biological environment in which biomaterials and biomaterials are located should be examined. Developments in the production and use of biomaterials, which are among the materials of the future, will greatly contribute to the realization of new designs. To know the requirements of biomaterials which are among the materials of the future, It will contribute to obtaining products to be designed.

Keywords: Biological environment; biological testing; biomaterials; biocompatibility.

\section{Giris}

Biyomateryallerde en önemli özellik biyouyumluluktur. Biyomateryallerin, bulunduğu ortamdaki dokularla uyum içinde bulunması ve gelişimine engel olmaması beklenir. Ayrıca ortamdaki dokuların iltihap ve pıhtı oluşturmaması gerekmektedir. Çünkü biyolojik ortama yerleştirilen yabancı materyal, ortam tarafından hemen kabul görmeyebilir. Bu durum biyolojik ortamın reaksiyon göstermesine neden olur. Biyolojik ortamın tepkisini önlemek için biyolojik ortama yerleştirilen materyalin biyouyumluluk özelliğinin yüksek olması yeterli olacaktır. Günümüzde geliştirilen birçok biyouyumlu metal, seramik ve polimer biyolojik ortamın değişik hücre ve dokularını onarmak ve yenilemek için kullanılmaktadır [1].

Biyomateryaller, hastaya uygulanan tedavi yöntemlerine uygun olacak şekilde işlenebilme özelliğine sahiplerdir. $\mathrm{Bu}$ işlemler gelişen ileri teknolojiler ve yapılan bilimsel araştırmalar sayesinde gerçekleştirilir. Kullanımdaki biyomateryallerin daha dayanıklı, sağlıklı ve biyouyumlu hale getirilmesi için araştırmalar yapılmaktadır. Yapılan çalışmalar sayesinde kullanılan materyallerin özellikleri gelişmekte ve yeni materyaller elde edilmektedir. Son yıllarda, biyomateryal/doku etkileşimleri üzerine önemli araştırmalar yapılmaktadır. Bu çalışmalar sayesinde, zarar görmüş hücre ve dokuların yeniden yapılandırılması için biyouyumluluğu yüksek materyaller geliştirilmiştir. Metalik biyomateryaller, biyoseramikler, polimerik biyomateryaller ve biyokompozitler günümüzde geliştirilen en iyi biyomateryallerdir. Nanoteknoloji kullanılarak geliştirilen birçok biyouyumlu medikal malzemelerde bulunmaktadır. Geliştirilen bu biyomedikal ve medikal olmayan materyaller farklı uygulama alanlarında yaygın olarak kullanılmaktadır [2]. Sağlık alanında kullanılan bu materyaller yüksek biyouyumlu biyomateryallerdir. Biyomateryallerin biyouyumluluk ve mekanik özelliklerinin iyileştirilmesine yönelik birçok çalışma yapılmaktadır. Biyomateryal bilimi incelendiğinde tıp, biyoloji, kimya, doku mühendisliği ve materyal bilimi unsurlarını içerdiği görülmektedir. Sağlık alanında kullanılan biyomateryallerin bazı temel özelliklere sahip olması gerekmektedir. Aranılan özelliklerde biyouyumluluk, biyoyıkılabilir olması, sinyal moleküllerine ve matriks yayılımına izin veren poröz yapıya sahip olması, toksik ve immunojenik olmaması, en uygun mekanik destekte olması gibi yaklaşımların bulunması arzu edilmektedir. Çok çeşitli uygulama alanları bulunan biyomateryaller cerrahi malzemeden, yapay deri ve organ uygulamalarına kadar geniş bir alanda kullanılmaktadir [3].

Biyomateryallerin sağlık alanında aldığı büyük yer nedeniyle, fızikokimyasal özelliklerinin belirlenmesinde yeni yaklaşımların ortaya konulması ve biyouyumluluk özelliklerinin tespitinde yeni metodların geliştirilmesi, yeni biyomateryallerin kullanıma sunulması son derece önemlidir.

\section{Biyomateryaller}

Günlük aktiviteler sırasında hücre ve dokular birçok değişime maruz kalmaktadır. Maruz kaldıkları bu şartlardan dolayı farklı özellikler gösterebilirler. Biyomateryaller, biyolojik ortamdaki değişken koşullar altında kullanılmaktadır. Bu nedenle değişen ortam şartlarına uyum sağlamaları beklenir. Elde edilen biyomateryallerin doğalına yakın özellikler sergilemesi durumunda sorun oluşmamaktadır. Biyomateryaller, biyolojik ortamdaki canlı dokuların işlevlerini yerine 
getirmek veya desteklemek amacıyla kullanılan doğal ya da sentetik materyallerdir. Biyolojik ortam protein ve oksijenli tuzlu çözeltiler içermektedir. Bu nedenle biyomateryallerden, biyolojik ortam sıvılarını bünyelerine alıp şişmemeleri, deforme olmamaları, korozyona uğramamaları gibi birçok özellik göstermeleri beklenmektedir. Bu şartlar dikkate alınarak üretilen materyallerin bazıları biyolojik ortam tarafından kabul edilmekte bazıları da kabul görmeyerek reaksiyona sebep olmaktadır. Ayrıca toksik ve kanserojen özellikte olmaması, mekanik dayanımlarının yeterli olması, biyolojik ortam reaksiyonları dışındaki reaksiyonlara sebep olmaması ve korozyona uğramaması gibi özellikler sergilemesi de gerekmektedir. Korozyon, biyomateryal seçiminde dikkat edilmesi gereken önemli bir konudur. Korozyon, biyomateryallerin bulundukları ortam ile istenmeyen bir kimyasal reaksiyona girerek oksijen, hidroksit ve diğer başka bileşikler oluşturması sonucu bozunması ve hasar görmesi demektir. Oluşan korozif ürünler doku içerisine girdiğinde hücre ve dokular bundan zarar görür. Biyolojik ortamda su, çözünmüş oksijen, protein, klorür ve hidroksit gibi çeşitli iyonlar bulundurması nedeniyle biyomateryaller için oldukça korozif bir ortamdır [4]. Bu korozif ortam, biyomateryallerin dayanımını düşürmekte ve hücrelere zarar vermektedir. Bu nedenle biyomateryallerin korozyona karşı dayanıklı olmaları gerekmektedir. Biyomateryal yüzeyinde oluşturulan pasif filmler sayesinde yüzeydeki oksitlenme önlenmeye çalışılmaktadır. Bu işlem sırasında kullanılan yüzey kaplama materyali büyük ölçüde biyouyumlu olmak zorundadır. Böylece biyomateryalin kullanıldığ 1 ortam tarafından kabul edilmesi çok daha kolay olacaktır. Biyomateryallerin biyolojik ortam sıvısı içinde minimum düzeyde çözünmesi ve ortamda kalma süresinin uzun olması istenmektedir. Uygulamalarda ortaya çıkan hücresel etkileşim en önemli unsurlardır. Hücrelerin biyouyumlu olan biyomateryal ile temasından sonra ortaya çıkan hücresel davranış uyumla ilgili gidişatın habercisidir. Bu durum biyomateryalin kullanıldığı ortamdaki uyumunun göstergesidir. Hücresel temastan hemen sonra gerçekleşen hücresel bazdaki değişimler bu etkileşimler sayesinde oluşmaktadır. Gerçekleşen hücresel değişim sayesinde hücre ile biyomateryal arasındaki etkileşimin boyutu ortaya çıkmaktadır [5].

Biyomateryaller, sadece protez ve implant malzemesi olarak değil, biyolojik ortam dışına yerleştirilen ve biyolojik ortamla etkileşim halinde olan cihazlarda da yaygın olarak kullanılmaktadır. İdeal bir biyomateryalde, fiziksel özellikler (mukavemet, elasitikiyet, dayanıklılık), işlenebilir, kolaylıkla steril edilebilir, nonallerjenik, nonkorozif, nontoksik, nonkarsinojenik, nonmutajenik, ucuz ve kolay üretim gibi özellikler taşıması beklenmektedir. Günümüzde kullanımda olan birçok ideal biyomateryal bulunmaktadır. Bu biyomateryallerin bazılarının kullanım ve uygulama alanları Tablo 1'de verilmektedir.

Tablo 1. Biyomateryal kullanım alanları ve uygulamalar

\begin{tabular}{|c|c|c|}
\hline & Kullanıldığı Yerler & Uygulama Alanları \\
\hline \multirow{7}{*}{ 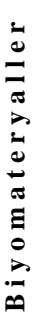 } & $\begin{array}{l}\text { Biyolojik ortamda hastalıklı ya da hasar görmüş organ ya da } \\
\text { uzuvların yerine }\end{array}$ & Diyaliz ve protezler \\
\hline & Biyolojik ortamda hasarlı organın fonksiyonelliğini arttırmak & Lens, kalp pili, işitme cihazı ve benzeri \\
\hline & Kozmetik sıkıntıları gidermek & Diş teli ve silikon yaptırma \\
\hline & Fonksiyon bozukluklarını gidermek & Omurgalardaki bozukluklar \\
\hline & İleri teknolojiler & $\begin{array}{l}\text { Kontrollu ilaç salımı ve taşınımı, organ ve } \\
\text { biyoalgılayıcı yapımı }\end{array}$ \\
\hline & Hasarlı bölgenin iyileşmesine yardımcı olmak & Ameliyat iplikleri, cerrahi vida ve teller \\
\hline & Hastalığın teşhisine yardımcı olmak & Endoskopi makinesi ve enjektör \\
\hline
\end{tabular}

Biyomateryallerin yapısal ve yüzey uyumluluklarını ayrı ayrı tanımlamak gerekmektedir. Biyomateryalin, biyolojik ortamdaki dokulara karşı fiziksel, kimyasal ve biyolojik açıdan uygun olmasına yüzey uyumluluğu denilmektedir. Biyomateryalin, biyolojik ortam dokularının mekanik davranışına sağladığı en uygun uyuma yapısal uyumluluk denilmektedir. Biyouyumluluğu yüksek olan biyomateryaller, biyolojik ortam içerisine yerleştirilen cihazların imalatında da kullanılmaktadır. 
Günümüzde nanoteknoloji kullanılarak geliştirilen birçok biyomateryal bulunmaktadır. Bu ileri teknoloji ürünü olan nanomateryallerin sağlık alanında farklı uygulamaları bulunmaktadır. Biyolojik uyumlu hale getirilen nanomateryaller canlı doku ve hücrelerde kullanılabilmektedir. Kullanılacağı ortama uygun hale getirilen nanomateryal yapılar da görselleştirilme problemi yaşanmaktadır. Çünkü boyutları nano mertebesindedir. Nanomateryalin boyutu kendisine çok büyük yüzey/hacim oranı sağlamaktadır. Aynı zamanda kümelenme, dağılma, emilim, boyut, yapı ve şekil durumu gibi özelliklerde bulunmaktadır. Nanomateryalin biyouyumluluk yüzey özellikleri ise taşıdığı yüklere ve kimyasal reaksiyona bağlıdır. Nanomateryallerin yüzey kimyası ve reaktivitesi sayesinde biyolojik dokuların etki ettiği materyalin yüzey etkileşim derecesi biyouyumluluğu seviyesini belirler [6]. Nanomateryallerin herhangi bir biyolojik ortamda nasıl davranacağı konusu hala tam olarak açığa kavuşturulamamıştır. Bununla birlikte, boyutları, yüzey yükleri ve kimyasal reaktivitesine dayanarak potansiyel tehlikeleri hakkında bazı öngörüler yapılabilmektedir. Temel olarak yüzey özelliklerinden faydalanılarak elde edilen bilgiler sayesinde öngörülemeyen yeni özellikleri ortaya çıkabilmektedir. Bundan dolayı biyolojik etkileşimleri hakkında kolayca öngörü yapılamaz [7]. Nanomateryallerim sağlık alanındaki sürdürülebilir gelişimini sağlamak için çeşitli uygulamalarda kullanılan nanomateryallerin risk değerlendirilmelerinin araştırılması gerekmektedir. Risklerin belirlenmesi için hem etki hem de maruz kalma değerlendirilmesinin yapılması gerekmektedir. Bu nedenle uygun analizler ve yöntemlerin kullanılmasına ihtiyaç duyulmaktadır [8]. Nanomateryallerin, bulunduğu ortamda maruz kalma ölçütünün değerlendirmesini yapmak için modelleme ve ölçüm yaklaşımı kullanılmaktadır. Her iki yaklaşımda da ölçülebilir fiziksel girdilerin değerlendirilmesine ve analitik tekniklere ihtiyaç duyulmaktadır. Modelleme yaklaşımı nanomateryallerin çevresel konsantrasyon tahmini, emisyon senaryolarına ve parçalanma parametrelerine bağlıdır. Analitik teknikler ise düşük konsantrasyonlu nanomateryallerin ölçülmesinde kullanılır. Analitik teknikler, laboratuvar analizlerinin ortamdan etkilenmeyen çevre koşullarını yansıtmasını sağlamak ve numunelerin bozulmasını önlemek için geliştirilmiştir. Bunlar dışında farklı yaklaşımlar ve çok sayıda analitik teknikler de kullanılmaktadır. Mikroskobik yaklaşımlar, kromatografi, santrifüjleme ve filtrasyon, spektroskopik gibi yaklaşımlar bunlardan sadece birkaçıdır. Bu teknikler sayesinde nanomateryal konsantrasyonu, özellikleri, tespiti ve karakterizasyonu hakkında bilgi elde edilmektedir. $\mathrm{Bu}$ nedenle, kompleks çevre matrislerindeki konsantrasyon ve nanomateryal karakteristiklerini belirlemek için uygun analitik yöntemlerin kullanılması gerekmektedir [9-10]. Böylece kullanılacağı ortama uygun nanomateryallerin seçimi gerçekleştirilir.

\section{Biyomateryallerin Başarısı}

Canlı hücre ve doku ile etkileşime girdiğinden, kullanılacak olan biyomateryal türü birinci derecede önemlidir. Bunu hastanın durumu ve uygulamayı yapacak kişinin alanındaki uzmanlığı takip etmektedir. Kimyasal bileşim, yüzey yapısı, sıvılar karşısındaki davranış, esneklik, aşınma direnci, elektrik yükü ve benzeri birçok önemli özellik kullanılacak biyomateryal türünü belirlerken göz önünde bulundurulmaktadır. Bu özellikler dikkate alındığında, kullanım amacına uygun biyomateryal türleri geliştirilir. Ayrıca farklı özelliklerde biyomateryallere ihtiyaç duyulması durumunda, modifiye edilebilir veya gerek görüldüğünde yeni biyomateryaller üretilebilir. Biyomateryallerin yüzeylerini diğer materyallerle kaplamak ya da bir kaç materyalin karıştırılmasıyla oluşan ve kompozit denilen maddeler üretmek günümüzde yapılan çalışmaların hedef ve yöntemleri arasındadır. Hedeflenen amaç ise ideal bir biyomateryal elde etmektir. Bir materyalin ideal biyomateryal olabilmesi için kullanıldığı ortama uyum sağlaması gerekmektedir. Biyouyumluluk ise cansız maddelerin kabaca canlı olanlarla biyolojik anlamda uyumunu ifade etmektedir. Biyouyumluluk denildiğinde, etkileşim veya temas halinde bulunduğu dokuların doğal süreçlerine engel olmayan ve dokuda istenmeyen tepkiler (zehirli atıklar, iltihaplanma, pıhtılaşma vb.) oluşturmayan anlamına gelmektedir. Operasyon sırasında veya sonunda kendisini çevreleyen hücre ya da dokuların normal değişimlerine engel olmayan ve istenmeyen tepkiler meydana getirmeyen 
materyaller biyolojik uyumlu materyallerdir [11]. Biyomateryallerin kullanıldıkları ortamda karşılaştıkları sorunlar Tablo 2'de verilmektedir.

Tablo 2. Ortam-biyomateryal ilişkisi

\begin{tabular}{l|l}
\hline & - Pihtılaşma \\
\hline & - Korozyon \\
- Kireçlenme & - Iltihaplanma \\
& - Hücre zehirlemesi \\
- Kan ile uyuşmazlık \\
- Mekanik özellikler kısıtlar (esneklik, \\
hafiflik, dayanım, yorulma, ömür)
\end{tabular}

Bir materyali biyomateryal yapan biyouyumluluk özelliğidir. Biyolojik ortamda kaybedilen veya doğuştan sahip olunmayan işlevlerin gerçekleştirmesi, doku ya da organların yerine konması ve bunu yaparken de zarar görmemesi kullanılan biyomateryalin biyouyumluluğuna bağlıdır. Biyomühendislik uygulaması olan biyomateryal bilimi biyolojik yapılar ile uyumlu materyaller üretmektedir. Bu çalışmalar sayesinde biyouyumlu materyallerin kullanımı artmakta ve hayat şartlarımız ve yaşam kalitemiz her geçen gün iyileşmektedir. Gelecekte bu materyallerin geleceğimizi nasıl şekillendireceği yapılan araştırmalarda gizlidir. İleride tamamen uyumlu yapay doku ve organların kullanılabileceği düşüncesini hayal etmek ise bizlere kalmıştır. Orijinali ile birebir aynı olan doku ve organlar geliştirildiğinde yaşam standartları yükselecektir. Biyoloji ortamda kullanılacak materyalin üstlendiği biyolojik fonksiyonu çevre dokulara zarar vermeden yerine getirmesi bazı temel özelliklere sahip olmasına bağlıdır. Biyomateryaller doğal temel özelliklere sahip olduklarında orijinal yedek doku ve organ kullanımı söz konusu olacaktır. Böylece yerleştirildiği ortamda bulunan dokular tarafından kabul edilmeme, materyalin biyolojik ortamda toksik etkiye neden olması ve çevre dokuların bundan zarar görmesi gibi durumlar ortadan kalkacaktır [12].

Biyomateryallerin biyouyumluluk derecesi üç özelliği bünyesinde bulundurmasına bağlıdır. Bu özellikleri içinde barındıran biyomateryaller biyouyumlu sayılır. Biyomateryaller, in-vivo ortamda lokal veya sistemik reaksiyona neden olmamalı, kaldığı ortam tarafından değiştirilmemeli ya da ortadan kaldırılmamalı ve kullanıldıkları yerin mekanik özelliklerine uyum sağlamalıdır. Günümüzde biyouyumluluk derecesini belirlemek için birçok farklı test yöntemleri kullanılmaktadır. Bu amaçla geliştirilen ilk test in-vitro test değerlendirme yöntemidir. Hücre kültürlerinin hücre büyüme oranı ve hücrelerin morfolojik özellikleri üzerindeki etkisinin değerlendirildiği yöntemdir. İn-vitro test yöntemi, biyomateryal vücuda yerleştirildiğinde malzemeye karşı oluşan biyolojik reaksiyonların test ortamında oluşturulması hedeflenmektedir. Bu test kullanıldığında biyomateryalin toksik özellikleri hakkında ön bilgi elde edilmektedir. İnsan ve deney hayvanları üzerinde yapılan uyumluluk testleri de bulunmaktadır. Bunlar ikincil test ve kullanım testleri olarak adlandırılır. İkincil test deney hayvanları üzerinde yapılan uyumluluk testidir. Test edilecek materyal, fare, koyun, kedi, köpek ve domuz gibi deney hayvanlarıdır. Bu şekilde yapılan testlerde materyalle biyolojik çevre arasındaki etkileşim izlenmektedir. Değerlendirilecek test materyali klinik kullanıma uygun şekilde deney hayvanına yerleştirilmektedir. Bu 
şekilde elde edilen veriler in vitro testlere göre daha kapsamlıdır. Fakat biyolojik cevabın karmaşık yollarla elde edilmesi, sonuçların ölçülebilir olarak değerlendirilmesini zorlaştırmaktadır [13]. Kullanım test yöntemindeki değerlendirme ise, biyomateryal klinik kullanıma geçtiğinde ortaya çıkan durumun tanımlanması esasına dayanır. Bu testler, hayvan veya insanlar üzerinde uygulanabilmektedir. İnsanlar üzerinde yapılan testlere klinik deneme denmektedir. Bu testin yapılabilmesi için biyomateryalin klinik uygulamaya geçebilecek seviyeye gelmesi gerekmektedir. Kullanılacak biyomateryal son haliyle gönüllü olan bir insana uygulanır [14]. Biyomateryallerin uzun dönem etkileri araştırılmak istendiğinde değerlendirme süresi aylar veya yıllar alabilir. Yapılan klinik denemeler resmi kurum ve hastanın onayı alındıktan sonra uygulanabilir. Materyallerin biyouyumluluğu, klinik denemeleri içeren dinamik bir süreçtir. Tek bir testin kullanımı materyalin biyouyumluluğunu değerlendirmede tek başına yeterli olmayabilir [15]. Buradaki hedef biyomateryallerin uygulamalardaki başarısını artırmaktır. Testlerde elde edilen sonuçlar, değerlendirme işleminin daha homojen şekilde yapılmasını sağlar. Bu sonuçlar sayesinde ise ideal biyomateryal üretimi gerçekleştirilir. Sonuç olarak biyomateryalin uygulamalardaki başarısı artmış olur.

\section{Biyouyumluluk}

Biyomateryaller için en önemli özellik biyouyumluluktur. Kendisini çevreleyen dokularla uyum içinde olması ve dokuların gelişimine engel olmaması, dokuda iltihap ve pıhtı oluşturmaması gerekmektedir. Biyomateryal ve biyouyumluluk terimleri, materyallerin biyolojik aktivitelerini belirlemek için kullanılır. Biyolojik uyumlu olan bir materyal biyomateryal olarak adlandırılmaktadır. Biyouyumluluk ise uygulama sırasında materyalin biyolojik ortam sistemine uygun cevap verebilme yeteneğidir. Biyouyumluluk kavramı geniş bakış açısıyla ele alındığında, yüzey ve yapısal uyumluluk başlığı altında incelenmektedir. Yapısal biyouyumluluk, biyomateryal yapısının etrafını saran dokuların mekanik özelliğine bağlı uyumudur. Yüzeysel biyouyumluluk ise biyomateryal yapısının etrafını saran dokularla fiziksel, kimyasal, biyolojik ve morfolojik olarak uyumlu yüzey özellikleri göstermesidir. Biyomateryal karakterizasyonunda kullanılan birçok parametre Tablo 3 'de verilmektedir.

Tablo 3. Biyomateryal karakterizasyon paramatreleri

\begin{tabular}{l}
\hline Biyomateryal karakterizasyonunda kullanılan parametreler \\
\hline - Mekanik özellikler (stress / strain davranışı, viskoelastiklik) \\
- Termal özellikler (erime / donma noktası, termal iletkenlik) \\
- Yüzey özellikleri ve adezyon kuvvet \\
- Elektriksel özellikler \\
- Optik özellikler \\
- Yoğunluk ve porözite \\
- Akustik ve ultrasonik özellikler \\
- Difüzyon özellikler
\end{tabular}

Fonksiyonunu veya görevini yerine getiremeyen hücre ya da organların yerine biyouyumlu materyaller kullanılır. Biyomateryaller ortama yerleştirildiğinde tam anlamıyla kabul edilir ya da tam anlamıly kabul edilmez. Bazen de kullanıldığı ortamda yan etki oluşturur. Bir biyomateryalden beklenen, yan etki oluşmadan kullanıldığı ortam tarafından kabul görmesidir. Biyomateryaller için, kullanılacağı yerin özelliklerine uygun tasarım yapılması büyük önem taşımaktadır. Biyomateryallerin kullanım şekline ve yerine göre istenilen fiziksel, kimyasal ve mekanik özelliklere sahip olmasının yanında kullanılacağı ortama uygun şekilde tasarlanması da gerekmektedir [16]. Biyolojik ortamlarda kullanılan biyomateryallerin tasarımı, birbiri ile etkileşen dinamik unsurlardan dolayı son derece zordur. Biyomateryal yüzeyinin kimyasal yapısı, biyomateryal-doku yüzey tabakasının kimyasal yapısı ve biyomateryal-konakçı hücrenin oluşacak biyomateryal-doku etkileşimine yanıtı gibi dinamik unsurlar dikkate alınmalıdır [17].

Biyolojik uyumluluk vücudun biyomateryali kabul edebilirliğinin ölçüsüdür. $\mathrm{Bu}$ yüzden biyomateryal ve uygulandığı ortam dikkatlice incelenmelidir. Biyomateryaller, kullanıldığı ortama zarar vermeyecek şekilde uyum 
sağlamak zorundadır. Biyomateryallerin biyouyumluluğu, uzuvların ve organların tedavisinde oldukça önemlidir. Yeni biyomateryal geliştirilmek istendiğinde, biyolojik ortamda istenmeyen bir etkiye neden olmamaları için detaylı şekilde biyolojik testler uygulanır. İlk önce biyolojik ortamın dışında daha sonra da ortam içerisinde testler yapılmaktadır. Sonra klinik denemelerle materyalin biyolojik güvenilirliği ve performansı tespit edilmektedir [18]. Biyomateryaller, değişken koşullara sahip bir ortamda kullanılmaktadır. Biyomateryallerin bu ortam koşullarına dayanıklı olmaları gerekmektedir. Geçmişte yapay materyallerin biyomateryal olarak kullanımı deneme yanılma yoluyla yapılmıştır. Böylece organ ve hücrelerin biyomateryallere karşı verdiği reaksiyonların tespiti yapılmıştır. Böylece kullanılan biyomateryallerin organ ve hücrelere zarar verip vermediği anlaşılmaya çalışılmıştır. Özellikle canlı ve cansız materyaller arasında çok büyük farklılıklar söz konusudur. Bu nedenle biyomateryallerin kullanıldığı bölgeye göre özenle seçilmesi gerekmektedir [11].

Biyomateryal çevresinden alınan doku örneklerinin morfolojik incelenmesi sonucu biyomateryallerin biyolojik uyumluluğu hakkında bilgi alınmaktadır. Elde edilen bilgiler sayesinde, oluşan biyolojik etkilerin tespiti yapılmaktadır. Yapılan bu araştırmalarda biyomateryal-konakçı etkileşimi belirlenir. Bu biyolojik etkiler dikkate alınarak sınıflandırma yapılmaktadır. Yapılan sınıflandırma biyotolere etki, biyoinert etki, biyoaktif etki, toksik etki ve rezorbe olabilen biyomateryaller şeklinde sıralanmaktadır [19].

Biyomateryaller uygulandığı ortamda fibröz doku ile çevrelendiğinde biyotolere etki söz konusu olmaktadır. Günümüzde kullanılan biyomateryalerin çoğunda bu etki görülmektedir. Biyomateryaller uygulandığı kemik dokusuyla fibröz bir dokuya ihtiyaç duymadan birleşirler. Biyomateryaller çoğu zaman uygulandıkları dokuyu, dokularda kendilerine uygulanan metaryali etkilemektedir. Bu tür etkileşimlerin görülmediği biyomateryal-doku ilişkisinde biyoinert etki görülmektedir. Poröz yapıdaki materyaller, yüzey alanının genişliğinden dolayı iyi bir biyolojik tespit sağlamaktadır. Yaşlanmış, zarar görmüş ve hastalanmış doku uygulamalarında bu durum söz konusu değildir. Farklı doku rejenerasyonu ihtiyaçları için yeni biyomateryal geliştirme araştırmaları yapılmaktadır. Materyallerin dokuya yerleştirilmesi sonucu bir seri biyofiziksel ve biyokimyasal tepkime gerçekleşir. Nihayetinde ise doku ile materyal ara yüzü arasında mekanik olarak güçlü bir bağlantı kurulur. Bu bağlantı, çoğunlukla biyoaktif materyal ile kemik arasında oluşur. Ancak yumuşak dokuyla da bağlantı gerçekleşebilir. Bu durumda biyoaktif etki gerçekleşir. Sağlık alanında kullanılan biyomateryaller, birçok farklı testten geçtikten sonra biyouyumluluk dereceleri belirlenir. Tüm bu testlere rağmen biyomateryallerin allerjik, immün, nonimmün, mutajenik, kanserojenik ve inflamatuar etkileri olabilir. Bu nedenle, kullanılacak biyomateryalin test işlemleri çok önemlidir. Bu yapılan testlerde toksik etki araştırması dikkatle yapılır [20]. Rezorbe özelliğine sahip biyomateryaller çözündükçe yerini konak doku almaktadır. Geçici dolgu materyali olarak dokuları birbirine bağlamak, zayıflamış dokuları geçici olarak güçlendirmek ve destek olmak amacıyla bu materyaller kullanılmaktadır. Çözünen materyal ile yeni doku oluşum hızının aynı olması gerekmektedir. Kullanıldı̆̆ ortamda materyalin çözünme ürünleri fizyolojik olarak kabul edilmelidir. Doku mühendisliğinde rezorbe olabilen materyaller, klinik uygulamalarda yaygın olarak kullanılmaktadır.

Doku mühendisliğinde ilk yıllarda hedef, kimyasal olarak mümkün olan en iyi inert materyaller üretebilmektir. Bu amaçla iskelet sisteminin tamirinde kullanılan ilk inert materyaller metallerdi. İnert biyomateryal ile tıp ve diş hekimliğinde birçok başarılı klinik uygulamalar bulunmaktadır [13]. Kullanılan bu İnert materyaller, biyolojik ortamın yüksek korozif özelliğine uzun süre direnç gösterebilir. Ancak materyal çevresinde materya ile yapışık olmayan fibröz bir kapsül meydana gelir. Bu durumda materyal-konakçı doku arasında bir mesafe oluşur. Başka bir deyişle materyal yüzeyinde kemik oluşumu gerçekleşir. Ancak konakçı doku ile arasında bağlanma gerçekleşmez. Böylece, inert olan materyal canlı dokuya mekanik olarak bağlanır. Bu bağlantı şekli morfolojik fiksasyon olarak tanımlanır [21]. 
Biyomateryal tamamen inert değildir. Konakçı doku, az da olsa bir tepki gösterir. İnert metal implantlar, yüksek dayanıklılık ve korozyon direncine sahiptir. Dokuyla ara yüzündeki kimyasal ve biyolojik bağlantının az olmasından dolayı mikro hareketlilik söz konusu olmaktadır. İnert biyomateryallere örnek olarak çoğu seramik, titanyum ve titanyum alaşımları, alumina, karbon, polimer, krom-kobalt ve krom-kobalt-molibden alaşımları gösterilebilir [22].

Biyoaktif materyaller, biyolojik yanıt oluşturur ve doku ile ara yüzünde bağlantı sağlar. Biyoaktif camlar, biyoaktif cam-seramikler, apatit ve vollastonit cam seramikler, kalsiyum fosfat seramikler, biyoaktif kompozitler ve biyoaktif kaplama materyalleri gibi yapılar biyoaktif materyal örneklerdir. Ara yüzde oluşan kimyasal ve biyolojik davranışlara göre biyoaktif materyaller, osteoprodüktif ve osteokondüktif materyaller olarak sınıflandırılır. Osteoprodüktif materyaller, materyal yüzeyinde serbest stem hücrelerinin kolonize olmasını sağlamaktadır. Böylece biyoaktif materyal ara yüzde ekstra ve intrasellüler yanıt oluşturmaktadır. Osteokondüktif materyal ara yüzde sadece ekstrasellüler yanıt oluşmaktadır. Günümüzde üretilen biyoaktif materyallerin az bir kısmı osteoprodüktif aktivite göstermektedir [23]. Biyoaktif materyallerin ara yüz direncinde meydana gelen ayrılma koheziv ya da adeziv olmaktadır. Biyoaktif materyalde ayrılma, doku ile biyomateryal arasında gerçekleşmektedir. Farklı biyoaktif materyallerin biyoaktivitesi, materyal yüzeyinde oluşan kimyasal tepkimelere bağlıdır. Örneğin ağız florası, bakteriler, funguslar, mikoplazmalar, protozoonlar, bazen virüsleri de içeren, zaman içerisinde değişen geniş organizma topluluğundan oluşmaktadır. Ağız içerisinde kullanılan biyomateryaller bu organizma topluluğundan etkilenmektedir. $\mathrm{Bu}$ nedenle biyomateryal seçiminde organizmaların etkisi dikkate alınmalıdır [24]. Canlı, cansız bakteri türlerinin ve ürünlerinin, tükürük bileşenlerden oluşan ve ağzın sert dokularının üzerinde oluşturduğu çökeltiye dental plak denilmektedir. Biyolojik ortamda dental plağa bağlı hastalıklar (kardiyovasküler hastalıklar, bakteriyel pnömoni, diabetes mellitus vb) meydana gelmektedir. Dental plak, bir fokal enfeksiyonun sonucudur. Bu nedenle cam ilavesi yöntemi antimikrobiyal ajanlara alternatif olarak kullanılmaktadır. Bu şekilde mikroorganizmaların antimikrobiyal ajanlara karşı direncinin önüne geçilmesi hedeflenmektedir. Biyoaktif cam sisteminin çeşitli bakteri türleri üzerindeki etkisini görmek amacıyla yapılan araştırmalarda, streptococcus sanguis, streptococcus mutans, actinomyces viscosus, porphyromonas gingivalis, fusobacterium nucleatum, prevotella intermedia ve actinobacillus actinomycetemcomitans türlerini ilk saatte büyük oranda azalttığını ve 3 . saatin sonunda antibakteriyel etkinin arttığı görülmüştür [25].

Biyomateryal, uygulandığı dokuda benzer hücrelerin oluşumuna yardım ediyorsa biyoaktif etkiden söz edilir. Biyomateryalin, biyolojik ortam dokularına fiziksel, kimyasal, biyolojik uyumu ve vücudun mekanik davranışına sağladığı optimum uyum gibi özellikler sayesinde biyoaktif etki gerçekleşir. Biyouyumlu olan materyal, etrafını çevreleyen dokular üzerinde iltihaplanma, pıhtı oluşumu gibi olumsuz etkiler oluşturmaz. Biyomateryaller, üstün mekanik özelliklere ve biyouyumluluğa sahip olduklarından, kullanım yerlerine göre uygun özellikleri taşıması açısından seçimleri büyük önem arz etmektedir [26]. Kullanıldığı ortamdaki çeşitli iyonlar, metalik materyaller için korozif bir ortam oluşturmaktadır. Bu nedenle metalik materyallerden uzun süreli korozyon dayanımı göstermesi beklenmektedir. Uygun seçilmeyen bir metalik biyomateryal kullanıldığı ortamda korozyon sonucu çözünmekte ve doku içerisine girerek zarar vermektedir. Biyomateryal doku etkileşimi çok önemli olduğundan bu özellikler için önemli çalışmalar yapıllmaktadır. Araştırmalar sayesinde kullanıldıkları ortamda doğal dokuların yeniden yapılanmasının sağlanması için uyumlu olan biyomateryaller geliştirilmektedir [27]. Bu yüzden hem biyomateryal, hem biyomateryalin kullanıldı̆̆ incelenmelidir. Seramikler, metaller, polimerler ve kompozit biyomateryaller istenilen mekanik özelliklerinin yanında biyouyumluluğu, organlarının tedavisi ve değiştirilmesi oldukça önemlidir. Yeni biyomateryaller geliştirildiğinde, biyolojik ortam içerisinde istenilmeyen bir etkiye neden olmamaları için ortam dışında ve içerisinde biyolojik testler uygulanır. Biyomateryallerin çevresinden alınan doku örneklerinin morfolojik incelemesi sonucu biyolojik uyumlulukları 
hakkında fikir sahibi olunmaktadır. Kullanılan biyomateryaller birçok testten geçtikten sonra biyouyumluluğu onaylanır. $\mathrm{Bu}$ yüzden, kullanılacak biyomateryalin test sonuçları çok önemlidir [17]. Medikal sistemlerde kullanılan biyomateryallerin biyolojik performanslarını kullanımdan önce belirlemek için in vitro ve in vivo testler uygulanmaktadır. $\mathrm{Bu}$ testlerin çoğu kullanılması düşünülen medikal ürünün potansiyel toksisite özelliğini belirlemek içindir. Yapılacak uygulamalarda kullanılan testlerin uygun seçimi, anlamlı sonuçların bulunması ve gereksiz harcamalar dikkate alınmaktadır. Örneğin bir polimer, spesifik uygulama yapmak için uygun ise biyouyumlu olarak belirtilmelidir. Polimerler genelde biyouyumlu olarak belirtilmezler. Sadece spesifik uygulamalar söz konusu olduğunda bu özelliklerinden bahsedilmektedir. Biyouyumlu bir polimer istenilen kanser dokusuna uygun ligand ile hedeflendirilen nanopartiküller dışarıdan uygulanan manyetik alan ile sıcaklık artışına ve kanserli hücrelerin ölmesini sağlar [28].

Örneğin kontak lens materyali kornea yüzeyinde veya gözyaşında protein adsorblamamalıdır. Ancak kemik sabitleştirici materyallerde bu durum tam terstir. Çünkü doku ile temasın olabilmesi için iyi bir etkileşim gerekmektedir. Polimerlerin biyolojik uyumu yüzeyinde adsorblanmış proteinlerle, dokudaki hücrelerin yüzeyindeki reseptörler arasındaki spesifik ilişkiyle açıklanmaktadır. Materyalin porozitesi ve yapısı, implant materyali ile dokular arasındaki mekanik stress dağılımıdır. Biyouyumluluğu artırma çabaları seçicilik azaltma ve artırma da yoğunlaşmıştır. Örneğin, hücre yüzey ilişkileri protein adsorbsiyonundaki azalmayla veya protein adsorbsiyonundaki seçicilikle sınırlandırılmıştır [27]. Biyouyumluluğun eksik ya da yetersiz olduğu durumlar Tablo 4'de verilmektedir.

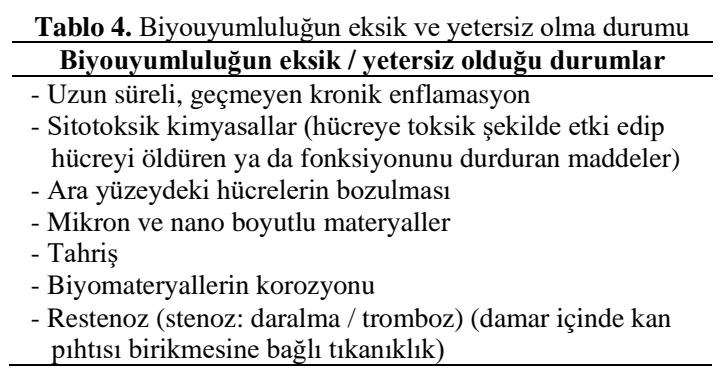

Biyomateryalin biyolojik ortamda oluşturduğu etkiye yanıt olarak oluşan doku cevabı, onun biyolojik uyumluluğunu belirlemektedir. Günümüzde biyomateryal üretiminde kullanılmakta olan materyallerin eksik yanları giderilerek, biyolojik ortam kullanım şartlarına daha elverişli materyallerin oluşturulmasına çalışılmaktadır. Bu sayede çok daha biyouyumlu biyomateryaller elde edilmektedir. Bu sayede canlı organizmalarda kullanılacak gelişmiş biyomateryaller üretilmektedir. Elde edilen biyomateryallerin kalitesi ise doğal olan yapılara benzerliğinin ölçüsüyle sinırlidir.

\section{Sonuç}

İhtiyaçlar doğrultusunda kullanılacak biyomateryallerin araştırılması ve yeni biyomateryallerin geliştirilmesi, farklı bilim dallarının bir araya getirilmesiyle mümkün olmaktadır. Modern tıbbı olumlu yönde etkileyecek olan farklı bakış açıları sayesinde sağlık problemlerinin erken teşhisi söz konusu olacaktır. Biyomateryallerin araştırma-geliştirme işlemleri sonucu, yeni tasarım kriterlerinin belirlenmesine imkân sağlanmaktadır. Yaygın klinik kullanıma geçilmeden önce bu materyallerin hücre ve dokular üzerindeki zararlı etkilerinin değerlendirilmesi gerekmektedir. Bunun için biyomateryallerin fiziksel ve mekanik özelliklerinin yanında biyouyumluluk yönünden de değerlendirilmesi gerekmektedir. Çünkü güvenilir materyallerin seçimine dikkat edilmesi biyomateryalin başarı şansını arttırmaktadır. 
Günümüzde insan sağlığına olumlu etkilerinin çok fazla olacağı düşünülen biyomateryallerin güvenilirlik ve etkinliği, in vivo ve in vitro biyouyumluluklarına bağlıdır. Biyomateryallerde üretilebilirlik, şekil verilebilirlik, kullanım esnasında maruz kalınacak gerilmelere karşı dayanım, biyouyumluluk, toksik etki ve biyolojik ortam sıvılarının korozif etkilerine karşı dayanımı gibi özellikler ön plana çıkmaktadır. Kullanılacak olan biyouyumlu materyallerin seçimi için, materyallerin biyouyumlulukları hakkında verilen bilgiler göz önüne alınmalıdır. Örneğin kullanılacak olan biyomateryallerin, korozyon açısından kişinin biyolojik yapısına uygunluğu, biyolojik ortam sıvılarından alınacak numuneler içinde veya buna çok yakın bileşimde hazırlanacak çözeltiler içinde test edilmelidir. Ayrıca uygulama işleminden önce, kişinin biyomateryallere karşı alerjik yapısı, çeşitli alerji testleri ile araştırılmalıdır. Bu uygunluk testleri biyomateryallerin uygulamadaki başarısını artıracaktır. Daha sağlıklı bir ekolojik çevre için çok daha biyouyumlu materyallerin geliştirilmesi gerekmektedir. Bu gerçekleştiğinde ekolojik çevredeki canlıların yaşam standartları artacaktır. Böylece daha sağlıklı bir yaşam süreceklerdir. Materyal bilimi, doku mühendisliği, fizik, kimya, biyoloji ve tıp gibi bilim dallarının multidisipliner olarak yürütecekleri çalışmalar sayesinde biyomateryallerin geleceği çok daha parlak olacaktır. Bu da yapay kalpten kalça protezlerine kadar birçok biyomateryal üretiminin artmasının yolunu açacaktır. Bunun için doğal dokuların yeniden yapılanmasını sağlayacak ileri teknolojilerin geliştirilmesi de gerekmektedir. Gelişen teknolojiler sayesinde gerçeğine uygun biyomateryaller elde edilebilecektir.

\section{Kaynaklar}

[1] Gür A.K., Taşkın M., "Metalik Biyomateryaller ve Biyouyum”, Doğu Anadolu Bölgesi Araştırmaları: 4, 2004.

[2] Teodorescu M., and Bercea M., "Poly(vinylpyrrolidone)-A Versatile Polymer for Biomedical and Beyond Medical Applications”, Polymer-Plastics Technology and Engineering, 54(9), 923-943, 2015.

[3] Dureja H., Tiwary A.K., “Gupta S: Stimulation of skin permeability in chitosan membranes”. Int J Pharm, 213, 193-198, 2001.

[4] Pasinli A., "Biyomedikal uygulamalarda kullanılan biyomateryaller”, Makine Teknolojileri Elektronik Dergisi, 25-34, 2004.

[5] Wafa I.A.F., Tao J., Gehan E.B., Cato T.L., "Synthesis, characterization of chitosans and fabrication of sintered chitosan microspherematrices for bone tissue engineering”. Acta Biomaterialia, 4, 503-514, 2007.

[6] Peter H., Bruske-Hohlfeld I., Salata O., “Nanoparticles -Knownand Unknown Health Risks”, Journal of Nanobiotechnology, 2(1), 12, 2004.

[7] Warheit D.B., Laurence B.R., Reed K.L., Roach D.H., Reynolds G.A., Webb T.R., “Comparative Pulmonary Toxicity Assessment Of Single-Wall Carbon Nanotubes In Rats”, Toxicological Sciences, 77, 117-125, 2004.

[8] Hassellov M., Readman J.W., Ranville J.F., Tiede K., "Nanoparticle Analysis and Characterization Methodologies in Environmental Risk”, Assessment of Engineered Nanoparticles. Ecotoxicology, 17(5), 344361, 2008.

[9] Gimbert L.J., Worsfold P.J., Haygarth P.M., "Processes Affecting Transfer Of Sediment and Colloids, With Associated Phosphorus”, From Intensively Farmed Grasslands: Colloid and Sediment Characterization Methods. Hydrol Processes, 21, 275-279, 2007.

[10] Mavrocordatos D., Perret D., Leppard G.G.. "Strategies And Advances in the Characterization of Environmental Colloids by Electron Microscopy. in: Wilkinson KJ, Lead JR, Editors. Environmental Colloids And Particles: Behaviour, Structure and Characterization. Chichester: Wiley, 345-404, 2007.

[11] Ayhan H., “Biyomateryaller”, Bilim ve Teknik, 2-11, 2002. 
[12] Hench L.L., Wilson J., “An Introduction to Bioceramics”, Chapter 1, p. 4, World Scientific, Singapore. 1993.

[13] Wataha J.C., “Biocompatibility of Dental Materials”, In Anusavice KJ, ed. Phillip's Science Of Dental Materials. Missouri: Elsevier Science, 171-202, 2003.

[14] Shigemasa Y., Minami S., “Applications of chitin and chitosan for biomaterials”, Biotechnol. Genet Eng Rev, 13, 383-420, 1998.

[15] Wataha J.C., "Principles of biocompatibility for dental practitioners”, J Prosthet Dent, 86, 203-209, 2001.

[16] Keskin A.O., "Hidroksiapatit seramiklerin mekanik özelliklerinin zirkonya ilavesi ile geliştirilmesi”, Yüksek Lisans Tezi, İTÜ, İstanbul, 2000.

[17] Gür A.K., “Ni-Ti Alaşımı Bir Biyomateryalin Üretimi ve İn-Vivo Şartlarda Biyouyumunun Araştırılması”, Fırat Üniv. Fen Bil. Enst.Yüksek Lisans Tezi, Elazığ. 2004.

[18] Mantovani D., “Sahpe Memory Alloys: Properties and Biomedical Applications”, Metals\&Materials Society, 36-44, 2000.

[19] Niinomi M., "Recently Metalic Materials for Biomedical Applications”, Metalurgical and Materials Transactions; Warrendale, 477-486, 2002.

[20] Levent U., “Ortopedide kullanılan biyomateryaller ve biyolojik yanıt”, GATA cerrahi ve travmatoloji ABD, TÜFTAD, Ankara, 32-37, 2006.

[21] Cao W.P., Hench L.L., “Bioactive materials”, Ceramic International, 22, 493-507, 1996.

[22] Zhang D., "In vitro characterization of bioactive glass”, Doktora tezi, Åbo Academi Üniversitesi, Turku, Finlandiya, 2008.

[23] Hench L.L., “Biomaterials: A forecast for the future”, Biomaterials, 19, 1419-23, 1998.

[24] Samaranayake L.P., “Essential Microbiology for Dentistry”, Churchill Livingstone. 2nd edition. Edinburgh, London, New York, 2002.

[25] Allan I., Newman H., Wilson M., “Antibacterial activity of particulate Bioglass ${ }^{\circledR}$ against supraand subgingival bacteria”, Biomaterials, 22, 1683-7, 2001.

[26] Güven Ş.Y., “Ortopedik materyallerin biyouyumlulukları ve mekanik özelliklerine göre seçimi”, Ulusal Tasarım Imalat ve Analiz Kongresi, Balıkesir, 472-484, 2010.

[27] Güven Ş.Y., Çetin H., "Metalik Biyomateryaller ve İmplantlar", S.D.̈̈. 15. Yıl Mühendislik Mimarlık Sempozyumu, 14-16 Kasım, SDÜ, Isparta, 175-181, 2007.

[28] Chichet A., Skowronek J., Kubaszewska M., Kanikowski M., "Hyperthermia-description of a method and a review of clinical applications”, Rep Pract Oncol Radiother, 12(5), 267-275, 2007. 